\title{
Embezzlement and Reckless Spending: A Bottleneck for Local Governments' Revitalization and Sustainable Development in Nigeria
}

\author{
Shafi'u Abubakar Kurfi \\ Department of Accounting \\ Umaru Musa Yar'adua University, Katsina State, Nigeria \\ E-mail: abubakarkurfishafiu@gmail.com \\ Moh'd Lawal Danrimi \\ Department of Accounting \\ Umaru Musa Yar'adua University, Katsina State, Nigeria
}

\begin{abstract}
Nigeria operates a federal system of government and power is allocated to federal, state and local governments. A collaborative effort was encouraged to promote socio-economic development. Unfortunately, lack of diversification of the economy and over concentration on crude oil, it now operates a monolithic economy. Federal government on monthly basis share the proceed to the three levels of government but ironically, nothing significant is shown for the huge allocations due to uncontrollable embezzlement and reckless spending by public servants more specifically local authorities due to the extreme closeness to citizenry. Documentary data were obtained from published books, reputable journals, government publications, magazines, newspaper publications, internet sources and personal observations in carrying out this study. The paper observed that embezzlement and reckless spending is on the increase in some Nigerian local governments and is manifested through the state joint local government account, embezzlements and reckless spending by local chairmen, fake projects, collusion in the transaction of government businesses, ghost workers, denial of statutory functions. The paper concludes that local government is at the verge of total collapse if adequate measures were not taken to savage the situation. The paper recommends that states joint accounts should be scrap for local governments have a sustainable development.
\end{abstract}

Keywords: Local Government, Embezzlement, Reckless Spending, Sustainable Development.

\section{Introduction}

Nigeria operates a federal system of government and powers are shared among the component units. This is indicative that local government is the third tier of government and is expected to be autonomous in the discharge of its duties. This was the essence of the various reforms at the grassroots governance, especially, the 1976 local government reform that among others recognised the council as a third tier of government and with powers to execute certain functions (Nwaodike, 2016). However, after many years of experimenting with the local government system, scholars have expressed concern over the parlous state of local councils in Nigeria and the apparent disconnect between it and the lives of the people. Therefore, if anyone is to examine the reasons for Nigeria's underdevelopment and the state of the nation, one should visit the local councils (Fatile \& Okewale, 20I4). Consequently, the councils have failed to deliver in its responsibilities.

This non-performance can be traced to many factors such as corrupt practices which include embezzlements and reckless of treasuries, lack of local autonomy, and lack of qualified personnel/manpower among others. Recently, there are so many allegations that state governments have consistently interfered on the political, financial and administrative functions of the councils and have created a master-servant relationship between the state and the local government which also lead to embezzlements and reckless spending in local governments in Nigeria (Adeyemi, 20I2).

Local government system in Nigeria witnessed abysmal failure. It is on record that at no time in the history of the country has there been the current level of funding accruing to the local governments from the Federal, yet the hope for rapid and sustained development has been a mirage as successive councils have grossly under-performed in their assigned responsibilities. This observation shows among others that local governments have produced exactly opposite the original objectives for their creation. Ukiwo (2006) maintained that, instead of bringing government and development closer to the people, local governments have produced absentee local government Chairmen who are seen at council headquarters when the monthly 'Abuja Allocations' arrives 
and vamoose with their standby jeeps and mobile police escorts after superintending over the sharing of the local governments share of the national cake among relevant stakeholder.

The Nigeria State is characterized by prebendalism. This is a situation where public office is held first, for the interest of the officer and second, for the interest of the public. This situation has greatly encouraged embezzlements at every level of government in Nigeria. Embezzlement mean to steal, misdirect or misappropriate funds or assets placed in one's trust or under one's control. From a legal point of view, embezzlement need not necessarily be or involve corruption. An example of embezzlements at local government is using local government fund to finance political parties. Izueke (2010) observed that collusion is also a powerful tool of embezzlements and reckless spending. Collusion is an arrangement between two or more parties designed to achieve an improper purpose, including influencing improperly the actions of another party. He identified the following forms of collusion that are common to the local government system in Nigeria and served as bottleneck for local governments' revitalization for sustainable development from the grass root. This collusion includes:

- Collusion between supervisory ministries and local government chairmen;

- Collusion with citizen who benefit from the thieving public officers;

- Collusion with contractors to inflate contract prices or quotation.

Therefore, the main aim of this paper is to identify how embezzlement and reckless spending become a bottleneck for Local Governments' revitalization for sustainable development. In this paper, local government and local councils are used interchangeably.

\section{Local Government, Embezzlements and Reckless Spending}

According to the United Nations Division of Public Administration, Local Government is a political division of a nation, which is constituted by law and has substantial control of local affairs including the powers to impose taxes or exert labour for prescribed purposes. Local Government is government at the local level created to decongest the functions and burden of the other tiers of government, bring about democratic climate of opinion; provide valuable political education, provide two-way communication; and ensure even and rapid development (Nwaodike, 20I3). It is usually created by a law of the State in a federal system of government and the law of the central government in a unitary state and given adequate power and autonomy to discharge the functions assigned to it. The governing body of such an entity is elected or otherwise locally selected (El-Rufai 20I2). This means that Local Government is a legally constituted body created for the grassroots level purely for developmental purpose (Olojede, Fajonyomi \& Fatile 20II). Ezeani (2004), also view local government generally as veritable agent of development and grassroots participation in the democratic process. The 1999 Constitution of the Federal Republic of Nigeria recognizes the local government as a legal rational entity. Section 7 says:

"The system of local government by democratically elected local government councils is under this Constitution guaranteed; and accordingly, the Government of every state shall, subject to section 8 of this Constitution, ensure their existence under A law which provides for the establishment, structure, composition, finance, and functions, of such councils". These definitions have basic features which include elective representatives, constitutionally recognised functions and powers to recruit personnel and generate revenue so as to execute its programmes (Nwaodike, 20I3).

Oviasuyi, Idada \& Isiraojie, (2010) maintained that the Constitution goes further to establish the function of the local government in its fourth schedule of both the 1979 and 1999 Constitutions of the Federal Republic of Nigeria, the basic functions, which all local governments in Nigeria are established to perform, revolve around the following:

- Functions in which success depends on communities' responsiveness and participation;

- Functions which require detailed local knowledge for efficient performance

- Functions which are of a personal nature requiring provision close to where the individuals affected live; and

- Functions in which significant use of discretion or understanding of individuals are needed.

Similarly, Nwadike, (2016); Oviasuyi, et al. (2010) spelt out other functions of Local Government Administration as

follows:

- The local government is authorized to consider and submit to a state commission or any other body on economic and social development as it affects the locality;

- The economic functions of local government enable the authority to raise money through investments, taxes and other forms of levies;

- The social and welfare functions of local government direct the authority towards the provision of such services as education, health, roads, and recreation grounds, etc,

- Local government administration also carries out informative functions such as enlightenment, development projects, administration, democratic and leadership initiative and maintenance of peace, law and order in the locality which may include:

- Inspection of meat and abattoirs;

- Provision of nursery, primary and adult education; 
- Provision of scholarship and bursaries award;

- Provision of public libraries and reading rooms;

- Agricultural and animal health extension services and veterinary clinics, fire services;

- Lighting and drainage;

- Support for arts and culture;

- Control of pollution;

- Control of beggars and prostitution;

- Homes for destitute, the insane and orphans;

- Public housing programmes;

- Regulation and control of buildings;

- Town and country planning;

- Operations of commercial undertakings;

- Control of traffic and parking;

- Pipe sewage systems.

However, most Local Governments in Nigeria have been unable to fulfil their obligations at the grassroots due to excessive external control from the states which impliedly lead to excessive embezzlements and reckless spending which is also bottleneck for local governments' revitalization for sustainable development.

Embezzlement is seen as a white-collar crime and its effect is felt by all tiers of government. The Federal Bureau of Investigation (FBI) defined embezzlement as, the illegal misuse or misapplication by a criminal to his/her individual benefit such as money, property, or some other thing of value entrusted to his/her care, custody or control. Edori (2018) included embezzlement as part of financial crimes in his list of financial crimes. It is an offense that occurs when an individual deliberately use assets and/or money for a purpose which it was not intended. According to the National White-Collar Crime Centre (NW3C) what differentiates embezzlement from other types of theft is the breach of financial trust between the property or money owner and the offender. They further explained that, embezzlement, technically, are a type of larceny and as a result does not enjoy a class of its own in the uniform crime reports so measurement of its number of occurrences is a bit difficult and may vary from source to source." Embezzlement is normally committed by employees that are entrusted with money or asset. Bartz, Strock \& Harris (2017) confirm that every organization both big and small, private and public is prone to embezzlement, they suggested different ways of preventing embezzlement such as segregation of duties and meticulous check of every transaction whether big or small.

Ibanichuka \& Onuoha (2012) maintained that embezzlement is an intentional misuse of money, physical assets or trust. The appropriation of money and other assets meant for a specific purpose for either personal use or for what it is not meant for. Such act is an unauthorized disbursement of money or other assets for personal gain. Embezzlement is the highest type of fraud in the public sector. People deliberately convert public fund to personal use without a blink of fear or conscience disturbance

The effect of embezzlement, reckless spending or any fraud is a bottleneck for Local Governments' revitalization for sustainable development and always unpleasant. Financial misappropriation or embezzlements in form of government has very negative effects as gathered by Kiabel (2002). Most embezzlement cases have serious socio-economic effects in the local authorities. It always results in loss of fund and assets of the local governments and has an adverse effect for revitalizing sustainable development. The loss of liquid assets will further lead to the reduction of revenue for current and capital expenditures, with the attendant reduction in the level of economic operations, reduction in revenue inflow and provision of socio-economic infrastructure for the public. Udoayang \& James (2004) spelt out this type of unethical behaviour is committed by the following means:

- Outright taking away of government assets for personal use

- Payment of salary for non-workers

- Payment for fictitious purchase and contract

- Payment for no return inwards

- Teeming and landing

- Manipulation of any form for personal gains

- Over-stating of the contract price

- Conversion of government money into personal use

- Conversion of office imprest to the personal allowance

- Unauthorized use of public funds or asset

- Payment against uncleared cheques

- The claim of disease staff gratuity and pension benefits

- Misuse of medical allowances and reimbursements

- Larceny 
- Cheque fraud and some fraudulent behaviour may include cutting costs and manipulating financial records for personal needs, etc.

\section{Trends of Embezzlements, Reckless Spending and Its Implications on Local Government Administration}

Aluko (2006) maintained that the local government reform of 1976 listed a single tier multi-purpose local government and ever since then, Nigeria as a country has adopted this form of local government administration. The implication of the above is that a similar method of corrupt practices is obtainable virtually in all the local councils in the country. The trends of embezzlements and reckless spending in Nigeria can be summarized as follows:

\section{I Council Chairmen}

Newswatch (200I) reported that in every state of the federation, council chairmen and other top local government officials have been accused of embezzlement, misappropriation of funds, extra-budgetary spending, purchase of official vehicles (sometimes unnecessarily) at unreasonably exorbitant prices, and outrageous expenditure on security. For example, in 2004 alone Punch (2004) reported that more than $\mathrm{N} 38.04$ billion as statutory allocation was disbursed to the 774 local governments in Nigeria; the question is what has really come of the huge amount? The simple answer is that it has given room for extravagant lifestyle on the part of the local council officials at the expense of the provision of essential basic socio-economic and infrastructural facilities for the local inhabitants. Newswatch (200I quoted in Aluko, 2006) reported that the chairman of Kachia local government area awarded a contract of N2.5 million for rehabilitation and completion of a women's centre but no work was done; he spent 1 , 9I3,990.00 on a rural electrification project, instead of the approved budget of $\mathbb{I}, 385,540.00$, the report further stated that the chairman of Sabon Gari LGA council ignored the provisions of the Financial Memorandum and gave each of his councillors $\$$ I50,000.00 for loyalty; he spent NImillion as touring allowance for the month of August 2000 alone; and spent another I.5 million on radio communication equipment. The same report had it that the extra-budgetary spending of the Samga local government chairman stood at 16,495,605.70; he even awarded a contract for office rehabilitation worth 3,I7I,375.00 when the value of the said office rehabilitation ought to be $906,044.00$.

Similarly, Ogun State local government cannot claim to be free from similar corrupt cases, on June I3, 20I0, Sunday Punch reported a case captioned " 30bn Fraud: EFCC Storms Ogun". In that report, former chairmen of Ikenne local government, Chief Adepegba Otemolu and Obafemi Owode local government, Mr Akeem Adesina were among the chairmen being investigated over the alleged diversion of $\mathrm{N} 30 \mathrm{bn}$ excess crude oil allocated to the 20 local government areas of the state in 2009 .

Adeyemi (2012) revealed that the former council chairman of Abeokuta North Local Government Council in Ogun State, Alhaji Morouf Ajisegun was convicted and sentence to two years imprisonment with the option of N500, 000.00 fine for lavishing the sum of N260, 000.00 meant for printing of exercise books in the local government on Ileya gift.

Fatile and Okewale (2014) also revealed that in Benue state, the Chairman of Ado LGA was reported to have spent thirty-eight million two hundred ( 38, 200,000.00) on maintenance of peace in the area where there was no crisis in the area since the Chairman assumed office. The Chairman also claimed to have spent eighteen million $\$ 18,000,000)$ on hospitality, the only LG Chairman in the country to have done so. Also, in Delta State, the Chairman of Okpe LGA was suspended by the, state House of Assembly on the allegation that he claimed have given N86 million to Niger Delta youths guarding pipeline installations. The chairman was further accused of mismanaging four hundred million $\quad$ 400,000.00) stabilization fund using his position to acquired 40 cars for himself and members of his family.

The above explanations and illustrations are few practical examples of embezzlement and reckless spending in local government councils in Nigeria. The consequence is a bottleneck for local governments' revitalization for sustainable development while the officials of the councils are busy celebrating their ill-gotten wealth.

\subsection{Ghost Workers}

Another trend of embezzlement and reckless spending in local government councils in Nigeria is ghost workers. The number of workers on the pay roll of the council is much more than the legitimate number of workers actually working in the council. Sometimes these ghost workers are regarded as consultants, liaison officers etc. in fact, some of these names do not exist in actual sense, that is, council officials only add such fictitious names and the money meant for such ghost names will finally find their way or be transferred to these officials account. Some ghost workers in some states are illegal names given by political office holders comprising their supporters who are not working but collecting wages/salaries from the local governments (Nwaodike, 20I3), this illicit act is a bottle necks for local governments' revitalization for sustainable development.

\subsection{Fake Projects}

Nwaodike, (2013) revealed that besides the aforementioned forms of embezzlement and reckless spending practices, others come in the form of fake projects as part of the ongoing developmental projects the councils claim to have embarked on. These unidentified projects include, drainage systems, lockup shops, construction of new and renovation of the existing ones respectively, 
agricultural projects like poultry farms, health centres for their staffs, etc. the council normally adds these projects as part of their achievement for the year but in real sense, such hardly exist. Hence, allocations meant for the budgeted projects are distributed among the local government officials to the detriment of the local people. Besides these, the councils have the habit of disbursing illegal funds to party leaders within the local government

\section{State Joint Local Government Account and its Implications on Local Government Administration}

Recently, there are allegations that state governments have consistently interfered on the political, financial and administrative functions of the councils and have created a master-servant relationship between the state and the local government (Nwaodike, 2013). The councils have not only become an appendage of the states, but the latter have also gone further to create a Joint Allocation Account Committee (JAAC) through their State Houses of Assembly to facilitate Section I62 (6, 7 and 8) of the I999 constitution as amended. This section created State Joint Local Government Account where federal/ statutory allocation between states and local governments are made. Monies statutorily allocated to the councils were alleged to have been siphoned by the chief executives of the states. This act has rendered the local government incapacitated especially in executing their assigned functions due to lack of funds. Therefore, a local government has become a shadow of themselves.

Aside the denial and starvation of monies meant for the local governments, there are illegal and sundry deductions from Joint Allocation Account Committee by the state government. It is on record that state governments deduct primary school teachers' salaries and allowances which are first line charges and they do not go into the state government purse. However, there are other deductions made from the State Joint Local Government Account. The percentage may look like stipends, but it amounts into millions of naira on monthly basis. These among others include:

- $\quad 1 \%$ training fund for Local Government Service Commission

- $\quad 4 \%$ for the traditional rulers (traditional council)

- $\quad 7.5 \%$ for employer contributions (contributory pension/NCPS)

- $5 \%$ redemption bond

- $\quad$ 15\% primary school teacher ${ }^{\text {ce }}$ pension

- Maintenance of Ministry of Local Government and Chieftaincy Affairs

- Contribution to SUBEB

- $0.5 \%$ life insurance premium

- $\mathrm{I} \%$ audit fees

- $\quad 15 \%$ local government staff funds

As a result of the above deductions, outright scrapping of the account was considered due to following reasons:

- Inability of the local government to carry out developmental projects at the grassroots.

- Irregular and times, non-payment of salaries and allowances of the local government functionaries

- To allow local governments to have financial and administrative autonomy

- To allow the existing local governments to function effectively in their duties

- To limit the overbearing influence from the state government

- To reduce unnecessary deductions from the local government account by the state government.

- To allow even distribution of dividends of democracy.

- To allow the elected political officers fulfil their promises to the masses in the local government area.

- It makes the local government to be at the mercy of the state government by going all about cap-in-hand begging for funds.

- To put an end to illegal deductions from the local government funds.

- To put a stop to the delay in the remittance of local government funds.

- To put a stop to unnecessary interference in local government affairs.

- For the harmonisation of local government funds.

State Joint Local Government Account denied local authorities to access full finance that help them to revitalize for sustainable development, thus, there is dire need to curb the above bottle necks by scrapping the Joint account.

\section{Conclusion}

It is obvious that most local government authorities are not functional enough to meet the need of its citizenry. With the exception of few local governments in the country, others are mere shadow of themselves. In terms of meeting their core mandate they have been largely ineffective and inefficient. This explains why after many years of comprehensive and democratically minded local government reform of 1976, little social dividends can be found in most local government. There is no doubt that the high rate of embezzlements and reckless spending in the local government has great negative implications. It is rather unfortunate that the citizens that are supposed to enjoy the benefits of these existing of local governments are rather subjected to all forms of ridicule 
and frustration by increasing insecurity, contagious disease, starvation to mention but a few in our local governments, thus, embezzlement and reckless spending serve as bottleneck for local governments' revitalization for sustainable development.

\section{Recommendations}

The following recommendations are some of the probable solutions to this scourge of fraud:

- Declaration of assets by the chief executive officer (Chairman) before assumption of office, and on leaving the office

- Establishment of vibrant project monitoring team from the state to monitor the pace of development in the local government area

- Establishment of an audit panel by the state to audit funds collected by the council in every six months

- Prosecution and conviction of persons found wanting. Government should go beyond the mere pronouncement of anti-corruption policies. It should rather provide good governance and an enabling environment for democratic ideals to thrive.

- Racing, seizing and confiscating all proceeds of crime

- Introducing or launching national reorientation programmes to educate people on the negative impacts and the need to eradicate corruption in all facets of Nigerian's public life

- The government must introduce an equitable wages and incentive system and improve other conditions of work so that the level of poverty could be reduced and the quality of life improved

- state joint local government account in Nigeria should be scrapped

- Financial Crime regulatory institutions should conclude all the outstanding financial fraud cases on the past Local Governments bosses that are all over the courts in Nigeria. This would help to some extent serve as a guide to upcoming politicians whom would be at the helms of affairs.

- Finally, there is the need for the provision of adequate resources anti-corruption agencies and non-interference of government on the mandate given to the anti-corruption agencies so as to make them effective.

\section{References}

Adeyemi, O. O. (2012). Corruption and local government administration in Nigeria: A discourse of core issues. European Journal of Sustainable Development, I(2), I83-I83.

Aluko, J. O. (2006). Corruption in the local government system in Nigeria. BookBuilders-Editions Africa.

Aluko, J.O. (2007). The Dynamics of Local Government Administration. Abuja: Bluesland Communication Limited.

Bartz, F., Strock, B., \& Harris, J. D. (2017). Embezzlement: Are you at risk?

Cavill, S., \& Sohail, M. (2007) Accountability Arrangement to Combat Corruption Water, Engineering and Development Centre Lougborough University Lekestershire UK

Duruji, M. M., \& Azuh, D. E. (2013). The Politics and Sociology of Corruption in Nigeria's Fourth Republic. ANSU. lou mal of Pence a)UI Development Studies, I(2), 65-86.

Simeon, E. D. S. E. I. (2018). Auditing and fraud control in corporate organisations. Auditing, 9(8), I90-196.

El-Rufai, N. A. (2012). Local Government: The Missing Tier of Government. Columnist (Internet material downloaded Feb IO, 20I4).

Ezeani, O. E. (2004). Local government administration Zik-Chuks Enugu

Fatile, J. O., \& Okewale, R. A. (2014). Corruption and democracy in Nigerian local government. Review of Public Administration and Management, I(3), I40-I55.

Izueke, E. M. (2010). Local Government and Good Governance in Nigeria. (Internet material downloaded Feb I3, 20I4.)

Islam, K. M. A., \& Barghouthi, O. A. (2017). Corporate Governance: An Islamic Institution Perspective. International Journal of Islamic Banking and Finance Research, I(I), 29-32. https://doi.org/I0.4628I/ijibfr.vI iI.36

Islam, K. M. A., \& Karim Miajee, M. R. (2017). An Islamic Perspective of Leadership. International Journal of Islamic Business \& Management, I(I), I4-I6. https://doi.org/I0.4628I/ijibm.vIiI.47

Islam, K. A., \& Bhuiyan, A. B. (2019). The Theoretical Linkages between the Shariah Supervisory Board (SSB) and Stakeholder Theory in the Islamic Financial Institutes: An Empirical Review. International Journal of Accounting \& Finance Review, 4(2), 43-49. https://doi.org/I0.4628I/ijafr.v4i2.436

Kiabel, B. D. (2002). Auditing: Basic Principles. Owerri: Springfield Publishers.

Newswatch, (200I). Looting of Local Government. Lagos, 33(25), 54-63.

Nwaodike, C. (2016). Corrupt practices in Nigeria's local government: A Critical Perspective. IOSR Journal of Humanities and Social, 2I(9), 6-II.

Nwaodike, C. A. (2013). Local Government Autonomy and Grassroot Democracy in Ogun State, Nigeria (I999-20I2). A Ph.D Thesis Submitted in the Department of Political Science and Public Administration, Babcock Business School, in 
Fulfilment of the Requirements for the Award of the Degree of Doctor of Philosophy in Political Science, Babcock University, Ilishan-Remo, Ogun State, Nigeria.

Olojede, I., Fajonyomi, S. B., \& Fatile, J. (Eds.). (20I I). Contemporary Issues in Local Government Administration in Nigeria. Rakson Nigeria (Educational Publishers).

Oviasuyi, P.O., Idada, W., \& Isiraojie, L. (2010). Constraints of Local Government in Nigeria. Journal of Social Science, 24(2), 8I-86.

Udoayang, I. O. and James, F. U. (2004). Auditing \& Investigation. Calabar. University of Calabar Press.

\section{Copyrights}

Copyright for this article is retained by the author(s), with first publication rights granted to the journal. This is an open-access article distributed under the terms and conditions of the Creative Commons Attribution license (http://creativecommons.org/licenses/by/4.0/). 